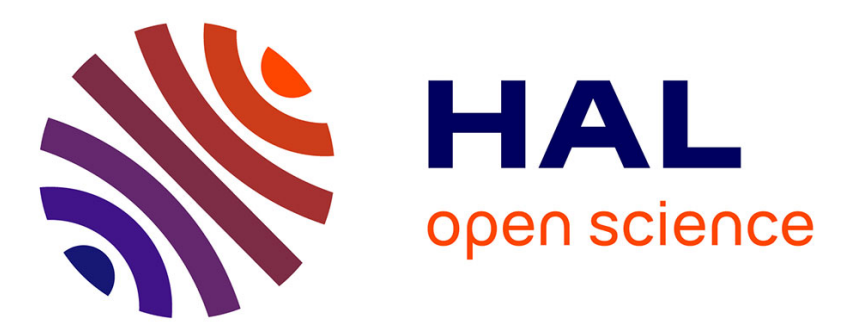

\title{
A microfluidic device with removable packaging for the real time visualisation of intracellular effects of nanosecond electrical pulses on adherent cells
}

Claire Dalmay, M. A. de Menorval, Olivier Français, L. M. Mir, Bruno Le Pioufle

\section{To cite this version:}

Claire Dalmay, M. A. de Menorval, Olivier Français, L. M. Mir, Bruno Le Pioufle. A microfluidic device with removable packaging for the real time visualisation of intracellular effects of nanosecond electrical pulses on adherent cells. Lab on a Chip, 2012, 12 (22), pp.4709-15. 10.1039/c2lc40857k . hal-00745203

\section{HAL Id: hal-00745203 \\ https://hal.science/hal-00745203}

Submitted on 11 Mar 2014

HAL is a multi-disciplinary open access archive for the deposit and dissemination of scientific research documents, whether they are published or not. The documents may come from teaching and research institutions in France or abroad, or from public or private research centers.
L'archive ouverte pluridisciplinaire HAL, est destinée au dépôt et à la diffusion de documents scientifiques de niveau recherche, publiés ou non, émanant des établissements d'enseignement et de recherche français ou étrangers, des laboratoires publics ou privés. 


\title{
A microfluidic device with removable packaging for the real time visualisation of intracellular effects of nanosecond electrical pulses on adherent cells
}

\author{
C. Dalmay ${ }^{1,}{ }^{*}$, M.A. De Menorval 2, 3,4, ${ }^{*}$, O. Français ${ }^{1}$, L.M. Mir ${ }^{2,3,4}$, \\ B. Le Pioufle ${ }^{1, * *}$ \\ * contributes equivalently to this work \\ ** corresponding author
}

${ }^{1}$ SATIE, CNRS, Ecole Normale Supérieure de Cachan, 61 av du Pdt Wilson, Cachan, France

${ }^{2}$ Université Paris-Sud, Laboratoire de Vectorologie et Thérapeutiques Anticancéreuses, UMR 8203, Orsay, F-91405

${ }^{3}$ CNRS, Orsay, Laboratoire de Vectorologie et Thérapeutiques Anticancéreuses, UMR 8203, F-91405

${ }^{4}$ Institut Gustave Roussy, Laboratoire de Vectorologie et Thérapeutiques Anticancéreuses, UMR 8203, Villejuif, F-94805

\section{Abstract}

The biological mechanisms induced by the application of nanosecond pulsed electric fields (nsPEFs: high electrical field amplitude during very short duration) on cells remain partly misunderstood. In this context, there is an increasing need for tools that allow the delivering of such pulses with the possibility to monitor their effects in real-time. Thanks to miniaturization and technology capabilities, microtechnologies offer great potentials to address this issue.

We report here the design and fabrication of a microfluidic device optimized for the delivery of ultra short ( $10 \mathrm{~ns}$ ) and intense (up to $280 \mathrm{kV} / \mathrm{cm}$ ) electrical pulses on adherent cells, and the real time monitoring of their intracellular effects. Ultra short electric field pulses (nsPEFs or nanopulses) affect both the cell membrane and the intracellular organelles of the cells. In particular, intracellular release of calcium from the endoplasmic reticulum was detected in real time using the device, after exposure of adherent cells to these nsPEFs. The high intensity and spatial homogeneity of the electric field could be achieved in the device thanks to the miniaturization and the use of thick $(25 \mu \mathrm{m})$ electroplated electrodes, disposed on a quartz substrate whose transparency permitted to achieve the real time monitoring of the nsPEFs effects.

The proposed biochip is compatible with cell culture glass slides that can be placed on the chip after separate culture of several days prior to exposure. This device allows for the easy exposure of almost any kind of attached cells and the monitoring in real time while exposed to nsPEFs, opening large perspectives for potential uses of the developed biochips.

\section{Introduction}

Cell electropermeabilization is a well-known technique that requires a short duration and an intense electric field to destabilize the plasma membrane. This technique is now mature and used in the field of cancer therapies in order to enhance the efficiency of targeted delivery of materials like drugs, antibodies or genes [1-3]. 
Electropermeabilization results from an interaction between the applied electric field and the cell plasma membrane, which increases its permeability.

For a circulating cell (assumed to be spherical) the transmembrane potential $\boldsymbol{\Psi}_{\mathrm{m}}$ is time dependent, following the charging of the plasma membrane (1) [4-5].

$$
\Psi_{m}=f \cdot E \cdot R \cdot \cos (\theta) \cdot\left[1-e^{-\frac{t}{\tau_{m}}}\right]
$$

where $\mathrm{R}$ represents the cell radius, $\mathrm{f}$ is function of the cell geometry, $\theta$ stands for the angle between the electric field $\mathrm{E}$ and the cell radius vector. The time constant $\tau_{\mathrm{m}}$, characterizes the dynamics of the charge of the membrane [5]. The case of adherent cells is more complex, and some simulation study on cell tissues can be found in [6].

In the case where conventional electropermeabilization pulses are applied (such pulses having few $100 \mu \mathrm{s}$ duration), the transmembrane potential reaches $\Psi_{m}=f \cdot E \cdot R \cdot \cos (\theta)$, once $\mathrm{t}>>\tau_{\mathrm{m}} \approx$ order of $\mu \mathrm{sec}$. In this case, the cell membrane shields the electrical field that does not penetrate inside the cell, as long as the membrane is not permeabilised [7-8].

With the recent technical progresses in the field of pulsed power equipment, the use of ultra short duration pulses (typically 3 to $10 \mathrm{~ns}$ ) and high intensity (up to $100 \mathrm{kV} / \mathrm{cm}$ ), also called nanosecond pulsed electric fields (nsPEF) has been investigated. The nsPEFs, implying a high frequency electric field spectrum (from DC and above $100 \mathrm{MHz}$ ), are able to penetrate inside the cells, as the plasma membrane is shortcircuited at these working frequencies $\left(t<<\tau_{m}\right)$. Hence, nsPEFs are able to disturb the membrane of intracellular organelles as internal vesicles, mitochondria [9] or endoplasmic reticulum [10-11]. Nevertheless, we are at the beginning of this very exciting area of manipulating cell interior whose mechanisms remain still misunderstood.

In this context, researchers need tools allowing the real time visualization of cell perturbations induced by the application of nsPEFs. In particular, the microtechnologies offer high miniaturization capabilities allowing the generation of highly intense nanosecond electric fields, suitable to penetrate the intra-cytoplasmic compartment. Moreover, the use of transparent material to microfabricate such miniaturized devices allows real time imaging of the effects of such nanopulses.

Especially, the nanoporation of adherent cells requires a particular attention, as these cells need to be cultured and attached on a substrate to be in proper conditions mimicking usual cell environment, prior to nPEFs exposure. While many studies exist in the literature concerning the electropermeabilization of circulating cells on a chip [1216], including our work [17], very few developments of micromachined devices adapted to the electrical treatment of adherent cells can be found. Hence, we propose in this paper an original approach where adherent cells cultures, prepared ex-situ on conventional glass slides, can be reported on our microfluidic device, thanks to a specific design. With this approach, one given microdevice can be re-used and easily cleaned for many experiments, where cells are cultured on glass slides prepared separately in large numbers. This concept of removable packaging is here advantageously exploited for adherent cells exposure to nsPEFs and for the real time monitoring of the effects of the nsPEFs, focusing on the generation of internal calcium concentration peaks resulting of membranes nanoporation. 


\section{Materials and Methods}

\section{A. Microfluidic biochip design}

In this section we describe the design of the new microfluidic device (Fig.1(a)) that was specifically developed for the observation and study of the effects of nsPEFs on adherent cells.

Impedance matching aspects:

Due to the high voltages (up to $10 \mathrm{kV}$ ) applied to obtain the high field amplitude of the nsPEFs, the impedance matching with the nanopulser is crucial in order to prevent any damages of the electronic components. Indeed, the level of reflections of the transmitted energy back to the nanopulser depends on this matching, which in addition affects directly the transfer of energy to the cells [18,-20].

As the electric field is applied to the biological medium with thick electroplated gold electrodes, the impedance is mainly governed by the physical properties of this medium. The propagation along the electrodes can be neglected for the considered frequency spectrum of the nsPEFs which energy is mainly located in the range (0$100 \mathrm{MHz}$ ), when $10 \mathrm{~ns}$ duration pulses are considered [18,-20]. The medium is mainly conductive at low frequencies (for $f<\frac{\sigma}{2 . \pi . \varepsilon}$ ) and capacitive for higher frequencies, where $\sigma$ and $\varepsilon$ are respectively the conductivity and permittivity of the medium.

The impedance matching cannot be achieved for all frequencies but can be optimized in a large frequency bandwidth, where the medium is considered as a pure conductance, and which includes the main energy frequency range of the nanopulses.

To do so, the geometrical parameters of the device (thickness $t$ of the electroplated electrodes, the distance $d$ between these electrodes, the length $\mathrm{L}$ and height $\mathrm{H}$ of the micro channel) are adjusted to get the required $50 \Omega$ impedance for the [0 to $200 \mathrm{MHz}$ ] frequency bandwidth, suitable with the delivery of 10 ns nanopulses with the available nanopulser generator described later, in the experimental section [1721]. While $d$ and $t$ are respectively set to $d=150 \mu \mathrm{m}$ and $t=25 \mu \mathrm{m}, \mathrm{L}$ and $\mathrm{H}$ depend on the chosen architecture (see next section).

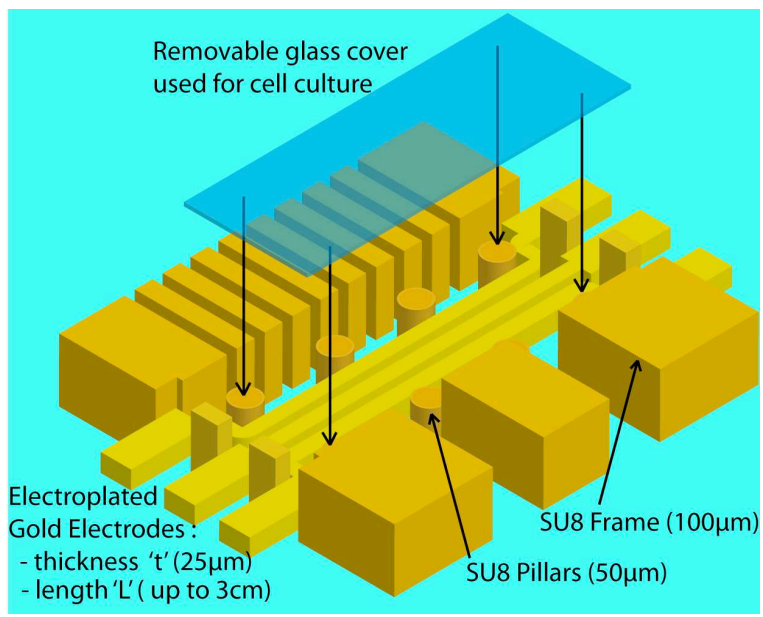

(a)

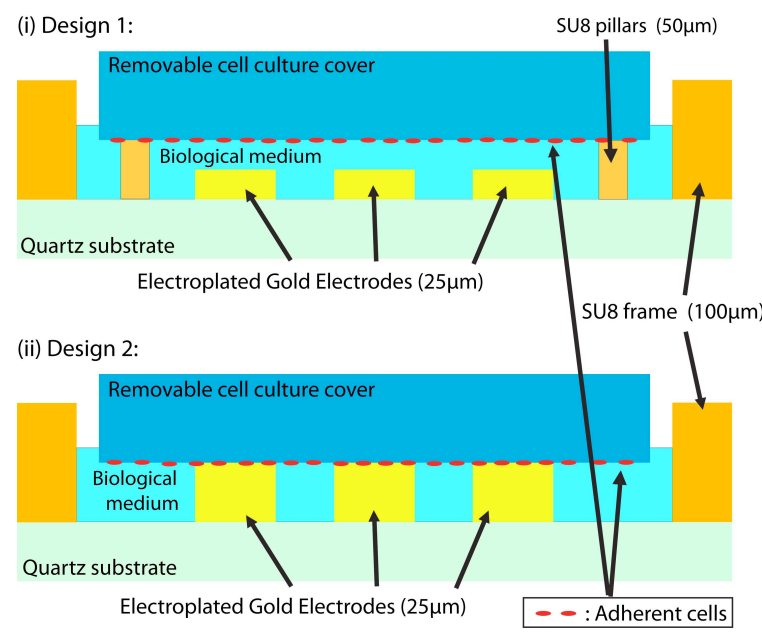

(b)

Figure 1: (a) Schematic representation of the device, involving electroplated gold electrodes in a transmission line configuration, and a thick SU8 resist frame for the centering of the removable glass 
cover. (b) The two designs of the microfluidic device with removable packaging, for cells exposure to nsPEFs: (i) Design with $25 \mu \mathrm{m}$ thick electrodes, and $50 \mu \mathrm{m}$ thick resist micro-pillars to support the culture slide (ii) Design with $25 \mu \mathrm{m}$ thick electrodes and no pillars (arbitrary scales).

Removable packaging architecture:

For adherent cells to be exposed to the nsPEFs solicitations, it is mandatory to let the cells incubate and adhere on the substrate prior to field exposure. An at least 4 hours incubation in sterile conditions, at $37^{\circ} \mathrm{C}-5 \% \mathrm{CO}_{2}$, is required. A cell culture directly performed within the microfluidic device is quite achievable but leads to several constraints i) only one or two exposures per day are possible, as $4 \mathrm{~h}$ are required for the adhesion and spreading of the cells, ii) a specific cleaning of the device is necessary after each experiment. The lifetime of the device is thus decreased, due to this needed cleaning procedure.

In order to avoid the drawbacks mentioned above, we developed a specific packaging, well adapted to our case where adherent cells are exposed to nsPEFs within the microfluidic device. The solution that we propose involves the possibility to use removable coverslip. Indeed this strategy presents the advantage to allow the culture on several cover slides in parallel while the biochip is available for short term (or even very short term) experimentations. The cleaning of the biochip is highly facilitated as the cell adhesion is not promoted within the channel surfaces. Thus, the device lifetime is increased.

The structure that we developed is represented on Figure 1.(b). Two different configurations have been investigated, each of them including an external frame in thick resist (SU8, Microchem) that allows the positioning of the $12 \mathrm{~mm} \times 32 \mathrm{~mm}$ culture cover slides above the metallic electrodes. Notches have been included in the SU8 layer to facilitate the slide removal after the nsPEFs application.

Considering the first design (Fig.1.(b)i.), cells are separated from the electrodes, and disposed at a distance controlled by micropillars height $(\mathrm{H})$ which are microfabricated in thick resist. Hence, this structure includes $25 \mu \mathrm{m}$-high gold electrodes, and $50 \mu \mathrm{m}$-high SU8 micro-pillars.

The second design (Fig.1.(b)ii.), which was finally chosen for the experiments, possesses the same $25 \mu \mathrm{m}$ thick electrodes, on which the removable slide covered with adherent cells is directly apposed. In that case, the length of the electrodes was adjusted $(\mathrm{L}=3 \mathrm{~cm})$ to achieve the impedance matching, taking into account the thickness $\left(\mathrm{t}_{c} \approx 7 \mu \mathrm{m}\right)$ of the cell layer cultured on the cover slide, and the conductivity $(\sigma=1.55 \mathrm{~S} / \mathrm{m})$ of the medium used. The thickness of the cell layer was estimated from the geometrical properties of DC3F cells (the cell type used in our experiments), and was confirmed by the actual measured impedance (see next section).

Once the culture slide is positioned in the SU8 frame, two spring strips are used to maintain it on the biochip.

Spatial homogeneity of the applied electric field pulses:

The culture slide being positioned above the metallic electrodes, as shown on Figure 1(b), the amplitude of the electric field depends on the location within the channel section. Hence, it is necessary to quantify the electric field attenuation to validate the feasibility of the cell nanoporation in this configuration. On Figure 2.(a), we compared the field distribution in the two design cases (with or without the $50 \mu \mathrm{m}$ resist pillars), using finite element analysis simulations performed with Comsol. We considered the thickness $t_{c}$ of the cell layers. 


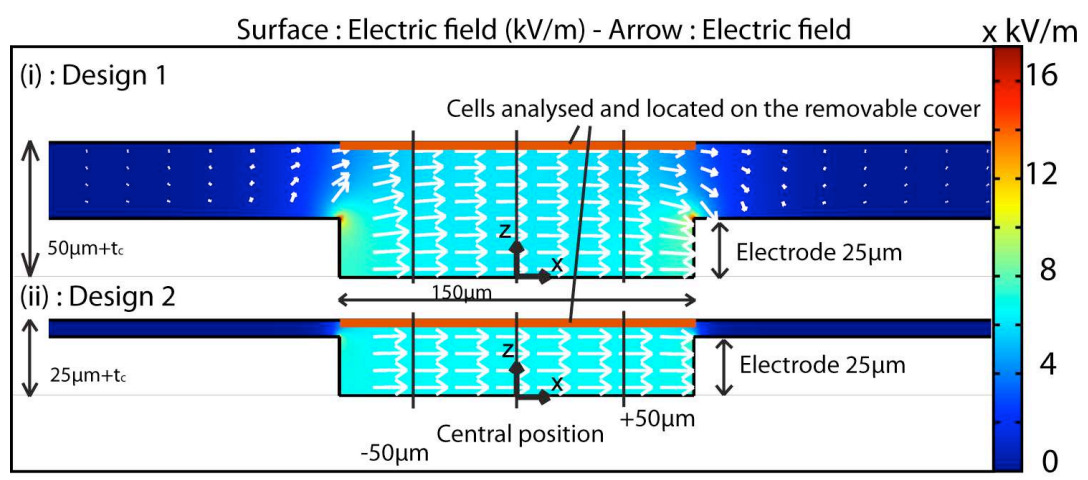

(a)
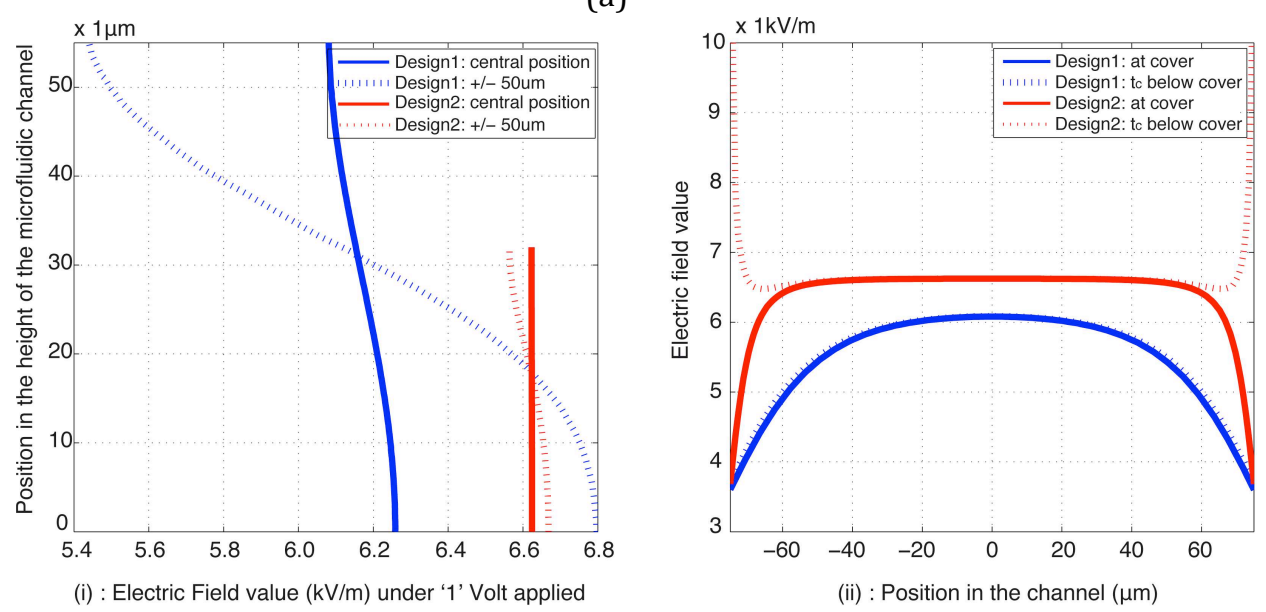

(b)

Figure 2: (a) Electric field calculation by finite element analysis, for the two designs developed for the nanoporation of adherent cells: (i) Design with the $50 \mu \mathrm{m}$ resist pillars and (ii) Design without the micropillars. The cell layer is taken into account (estimated at $t_{c}=7 \mu \mathrm{m}$ ). (b) Homogeneity of the electric field within the nanoporation channel (for $1 \mathrm{~V}$ ): (i) depending on the z position in the microfluidic chamber and (ii) depending on the $\mathrm{x}$ position of cells on the glass slide (from one electrode side to the other). Blue curves correspond to design 1 (with micro-pillars), while red curves correspond to design 2 (without pillars).

Figure 2.(b) displays the electric field dependence on the $\mathrm{z}$ position (Fig.2(b)i.) and the $\mathrm{x}$ position (Fig.2.(b)ii.) in the microfluidic chamber. The cell layer cultured on the cover slide, is confined between altitudes $\mathrm{z}=50-57 \mu \mathrm{m}$ in the case of prototype 1 and $\mathrm{z}=25$ $32 \mu \mathrm{m}$ for prototype 2 (considering the cell thickness does not exceed $t_{c}=7 \mu \mathrm{m}$ ).

This analysis shows that the variation of the electric field in a section of the microchannel remains quite acceptable in both structures, but that the best homogeneity (Table 1) is achieved with design 2 (without micro-pillars).

\begin{tabular}{|l|l|l|l|l|}
\hline & \multicolumn{2}{|c|}{$\begin{array}{c}\text { Homogeneity of the electric field as a } \\
\text { function of the z position in the } \\
\text { microchamber }\end{array}$} & $\begin{array}{c}\text { Homogeneity of the electric field } \\
\text { as a function of the x position in } \\
\text { the microchamber, over } 90 \% \text { of } \\
\text { the distance between the } \\
\text { electrodes }\end{array}$ \\
\hline & $\begin{array}{c}\text { Central position } \\
(0 \mu \mathrm{m})\end{array}$ & $\begin{array}{c}\text { Side position } \\
(+/-50 \mu \mathrm{m})\end{array}$ & $\begin{array}{c}\text { In contact with } \\
\text { the cover }\end{array}$ & $\begin{array}{c}\mathrm{t}_{\mathrm{c}}(7 \mu \mathrm{m}) \\
\text { below the } \\
\text { cover }\end{array}$ \\
\hline Design 1 & $2.85 \%$ & $21.9 \%$ & $28.9 \%$ & $27.1 \%$ \\
\hline Design 2 & $0.02 \%$ & $1.55 \%$ & $10.6 \%$ & $2.01 \%$ \\
\hline
\end{tabular}

Table 1: Spatial homogeneity of the electric field. 
Design 2 (25 $\mu \mathrm{m}$ thick electrodes, no thick resist pillars) seems to be the most appropriate design, if the field homogeneity criteria in the microchannel is considered as the most important criterion (Figs. 2.(a)ii., 2.(b), and Table 1).

Nevertheless, the design 1 (involving the $50 \mu \mathrm{m}$ resist pillars) has the advantage to prevent any contact between the cells and the electrodes. Indeed, such contact might alter the cell viability (due to electric field edge effects visible on figure 2.(b)ii.).

\section{B. Fabrication process}

Both proposed designs were fabricated on a quartz substrate, as it is transparent, has good dielectric properties and presents good adhesion properties. The materials used for the fabrication are biocompatible. The metallic electrodes are in electroplated gold as it is biocompatible and has a good conductivity (sigma $=4.1 \times 10^{7} \mathrm{~S} / \mathrm{m}$ ). The microfluidic chamber is patterned with a thick photosensitive resist (SU8, MicroChem), broadly used in bio-microfluidic devices.

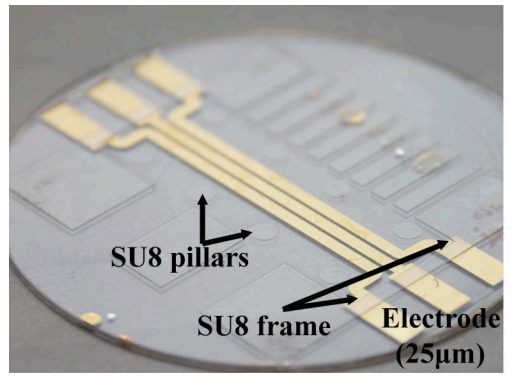

(a) Prototype 1

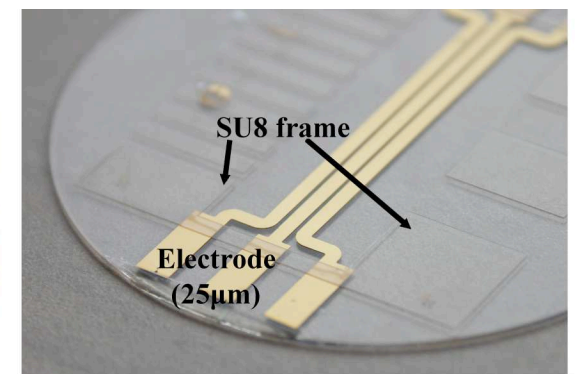

(b) Prototype 2

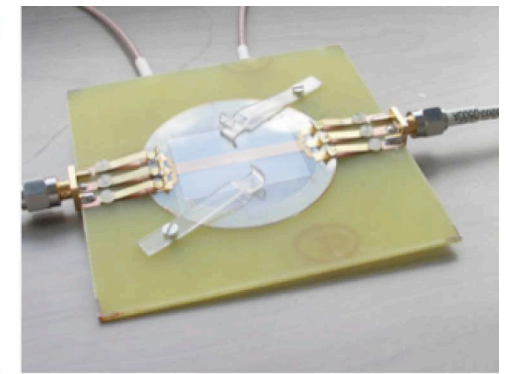

(c) Connected device

Figure 3: Photographs of the fabricated microfluidic devices. (a) prototype 1, with SU8 microstructured pillars and (b) prototype 2 without pillars; (c) general view of the device connected to the PCB (printed circuit board), with two springs to maintain the culture slide.

The process started with a quartz substrate (from ACM), which was premetallized with a $\mathrm{Cr} / \mathrm{Au}$ layer whose thickness was respectively $30 \mathrm{~nm} / 150 \mathrm{~nm}$. After a cleaning of the wafer with successively acetone, isopropanol, water baths and desorption at $150^{\circ} \mathrm{C}$, the gold thickness was increased up to $25 \mu \mathrm{m}$. The gold was electroplated using an $\mathrm{KAu}(\mathrm{CN})_{2}$ bath and a current density of $1.5 \mathrm{~mA} / \mathrm{cm}^{2}$. The gold electrodes were then patterned using UV photolithography of S1805 resist, followed by gold and chromium chemical etching.

The microchamber was then fabricated on the electrodes by the structuring of a SU8 layer using photolithography. Concerning the SU8 pillars design (prototype 1), a double SU8 layer was used to define the $50 \mu \mathrm{m}$ thick pillars and the $100 \mu \mathrm{m}$ thick SU8 frame. The first SU8 layer (SU8 2025) was spin coated to reach a thickness of $50 \mu \mathrm{m}(1700 \mathrm{rpm}$ for $30 \mathrm{~s}$ ), baked $\left(3 \mathrm{~min}\right.$ at $65^{\circ} \mathrm{C}$ and $15 \mathrm{~min}$ at $\left.95^{\circ} \mathrm{C}\right)$, exposed to $\mathrm{UV}\left(390 \mathrm{~mJ} / \mathrm{cm}^{2}\right)$ and post exposure baked $\left(3 \mathrm{~min}\right.$ at $65^{\circ} \mathrm{C}$ and $15 \mathrm{~min}$ at $95^{\circ} \mathrm{C}$ ). The second SU8 layer (SU8 2075) was then spin coated to reach a final thickness of $100 \mu \mathrm{m}(2100 \mathrm{rpm}$ for $30 \mathrm{~s})$. The resist was baked $\left(3 \mathrm{~min}\right.$ at $65^{\circ} \mathrm{C}$ and $15 \mathrm{~min}$ at $\left.95^{\circ} \mathrm{C}\right)$, exposed again $\left(600 \mathrm{~mJ} / \mathrm{cm}^{2}\right)$, post exposure baked $\left(3 \mathrm{~min}\right.$ at $65^{\circ} \mathrm{C}$ and $15 \mathrm{~min}$ at $\left.95^{\circ} \mathrm{C}\right)$ and the two layers were simultaneously developed. Considering prototype 2 (without the pillars), only one layer of SU8 (SU8 2075) was spin coated to directly reach the targeted thickness of $100 \mu \mathrm{m}$ (2100 rpm for $30 \mathrm{~s})$. The resist was then baked $\left(5 \mathrm{~min}\right.$ at $65^{\circ} \mathrm{C}$ and $20 \mathrm{~min}$ at $95^{\circ} \mathrm{C}$ ), exposed to UV $\left(600 \mathrm{~mJ} / \mathrm{cm}^{2}\right)$ and post exposure baked $\left(3 \mathrm{~min}\right.$ at $65^{\circ} \mathrm{C}$ and $15 \mathrm{~min}$ at 
$95^{\circ} \mathrm{C}$ ). The SU8 layer was finally developed to define the microfluidic chamber. Figure 3 shows photographs of the fabricated biochips.

\section{Cell preparation}

DC-3F cells (Chinese hamster lung fibroblast cells) were grown in MEM (Minimum Essential Medium) supplemented with 10\% fetal bovine serum, $100 \mathrm{U} / \mathrm{mL}$ penicillin and $100 \mu \mathrm{g} / \mathrm{mL}$ streptomycin. Cells were propagated at $37^{\circ} \mathrm{C}$ in a humidified $5 \% \mathrm{CO}_{2}$ atmosphere. Cells were routinely passed every two days. All the chemicals were purchased from Invitrogen (Cergy Pontoise, France).

For the biological experiments, cells were cultured on glass slides for at least 4 hours. In order to visualize the effect of nsPEFs on living cells, the slides were incubated for $30 \mathrm{~min}$ with the fluorescent calcium marker Fluo-4 AM $(\lambda e x=496 \mathrm{~nm}$, $\lambda \mathrm{em}=515 \mathrm{~nm}$ ) in a humidified atmosphere with $5 \% \mathrm{CO}_{2}$ at $37{ }^{\circ} \mathrm{C}$. The slides were washed three times with PBS and placed on the top of the chip (the cells being thus located inside the channel). Fluo-4 AM dye possesses acetoxymethyl groups (AM) allowing the molecule to enter the cells and preventing calcium binding outside of the cell. Once the marker is inside the cytoplasm, the AM groups are cleaved by endogenous esterases resulting in both the trapping of the fluorophore and its activation. If the cytosolic calcium concentration increases, Fluo-4 fluorescence increases. Hence, monitoring the fluorescence of exposed cells allows knowing if organite membranes or plasma membranes are affected by the nsPEF and become permeable to the calcium ions. Cells were exposed to a single $10 \mathrm{~ns}$ pulse of $280 \mathrm{kV} / \mathrm{cm}$.

DC-3F cell images were taken with a Zeiss AxioCam Hrc camera on a Zeiss Axiovert S100 epifluorescence inverted microscope controlled through the Axio Vision 4.6 software (Carl Zeiss, Germany).

D. Electrical set-up: nanosecond pulse generator and measurement

A commercial generator purchased from FID (FID GmbH, Model FPG 10-ISM10, Burbach, Germany) with an output impedance of $50 \Omega$ was used to treat the cells. It generates trapezoidal monopolar pulses with a full-width at half maximum of $10 \mathrm{~ns}$ [1820]. The output voltage magnitude goes from $3 \mathrm{kV}$ to $10 \mathrm{kV}$. The rising edge lasts between 0.4 and $0.6 \mathrm{~ns}$. The falling edge lasts between 1 and $1.5 \mathrm{~ns}$.

In order to characterize the incident and reflected signals in the exposure set-up, a tap-off (245 NMFFP-100, Barth Electronics Technology, USA) was connected between the generator and the biochip using two transmission lines [22]. The tap-off is a threeport device. The impedance of the mainline (i.e. the nsPEF-biochip line) is $50 \Omega$ whereas the impedance of the measurement port (i.e. the connection to the oscilloscope) is $4950 \Omega$, allowing a voltage measurement with a 1:100 ratio. A Wavemaster $808 \mathrm{Zi} 8 \mathrm{GHz}$ oscilloscope (LeCroy, Courtaboeuf, France) has been used for the measurements. 


\section{Results and Discussion}

Optimum architectures of the device have been investigated in order to ensure a good homogeneity of the cells exposure conditions within the microfluidic channel. Indeed, for this study concerning nsPEFs effects on adherent cells, that are attached on glass cover slides reported on the nanoporation device, nsPEFs should be very well controlled and spatially homogeneous.

As shown by finite element analysis, the homogeneity of the electric field is enhanced when the culture slide is directly reported on the $25 \mu \mathrm{m}$ thick electrodes (prototype 2), as far as we examine cells that are not directly in contact with the electrodes. The $25 \mu \mathrm{m}$ thick electrodes structure combined to $50 \mu \mathrm{m}$ resist pillars (Prototype 1) gives satisfying but lower homogeneity for the electric field as explained in section II.A. Therefore the prototype 2 ( $25 \mu \mathrm{m}$ thick electrodes, no pillars) has been employed to achieve the results presented thereafter.

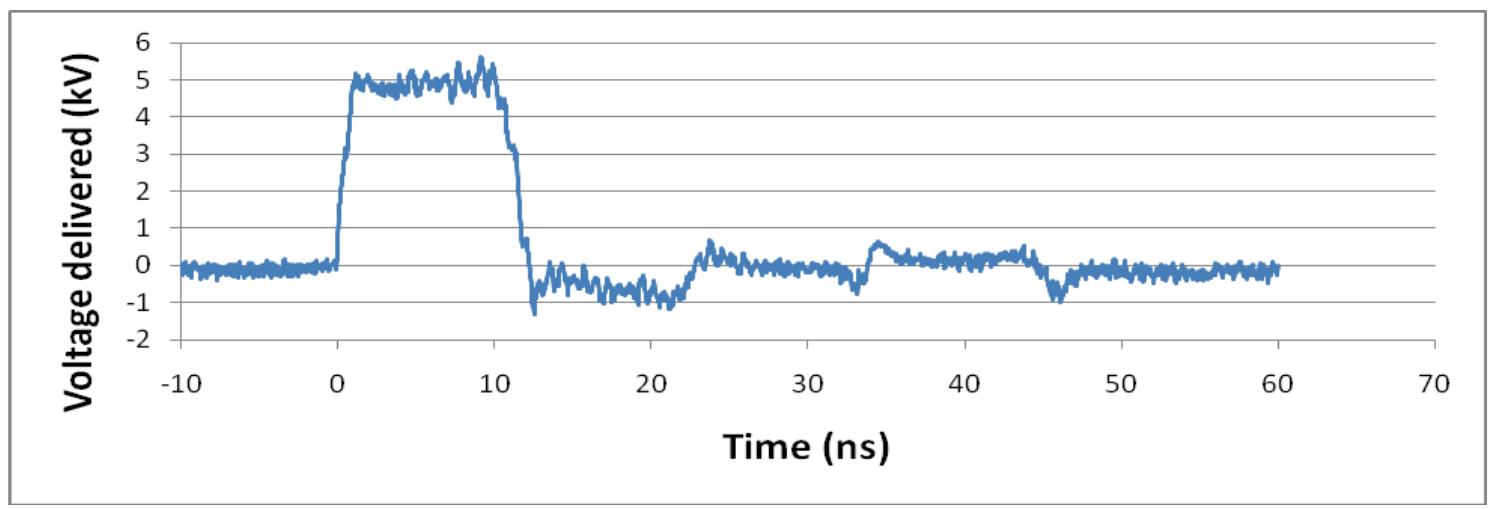

Figure 4: recording of the applied nsPEFs

To validate the possibility to expose cells reported on the top of the electrodes, biological experiments have been achieved and especially, we study the dynamics of the $[\mathrm{Ca} 2+]_{i}$ in response to the application of nsPEF. DC-3F cells were loaded with the calcium marker Fluo-4 AM. Cells were exposed to a single $10 \mathrm{~ns}$ pulse of $280 \mathrm{kV} / \mathrm{cm}$. The profile of applied nsPEFs is reported in figure 4. As predicted, a good impedance matching is achieved; around $5 \%$ of the nsPEF is reflected back to the nanopulser which gives an effective impedance of the chip equal to $45 \Omega$. This slight difference could be interpreted as an under-estimation of the cell layer height or some inhomogeneities in this height.

Concerning the cell exposure, recording started $100 \mathrm{~s}$ before the pulse, to visualize the baseline of the fluorescence, and continued for $10 \mathrm{~min}$ after the nanopulse delivery. Figure 7 reports typical results achieved under the experimental conditions reported here. As seen on the figure 5.(a), an increase in the Fluo-4 fluorescence in the presence of extracellular calcium, indicating a raise in the cytosolic calcium concentration, was observed. After $400 \mathrm{~s}$ the fluorescence was back to the baseline showing that the cells can recover this massive calcium release, probably through the activation of pumps and transporters. 
A

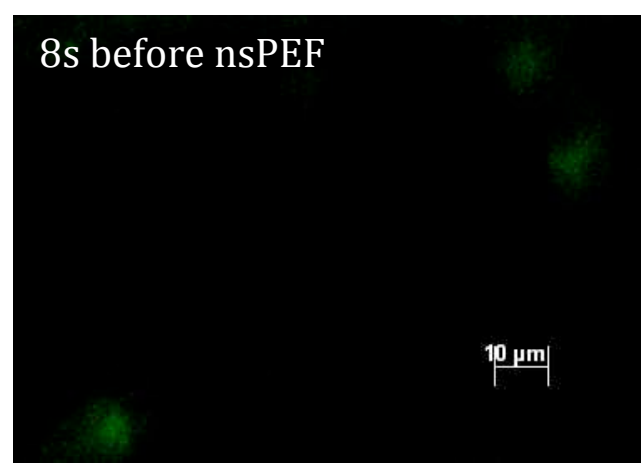

$\mathrm{C}$

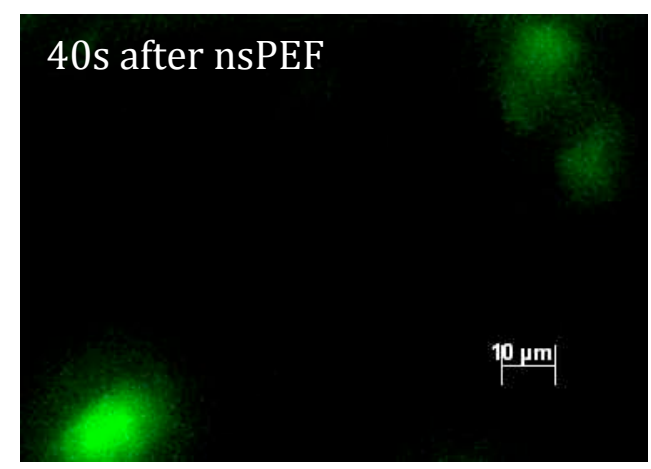

$\mathrm{B}$

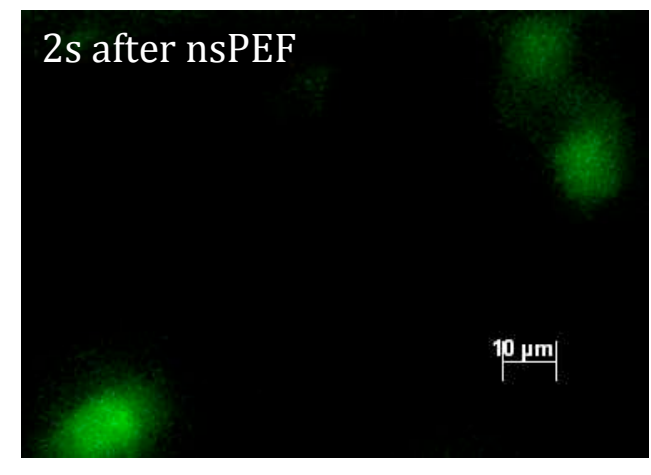

$\mathrm{D}$

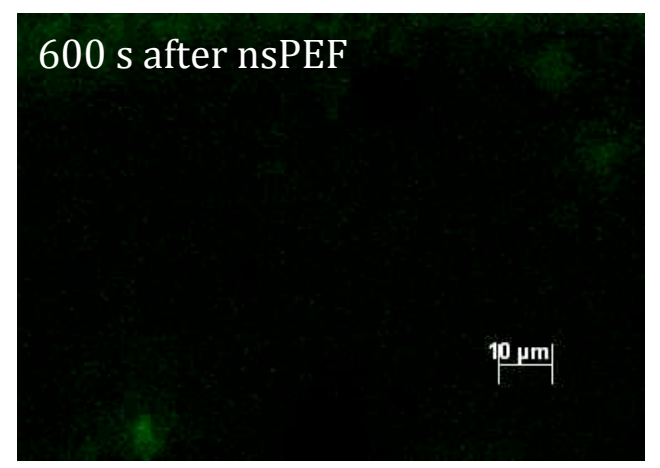

(a)

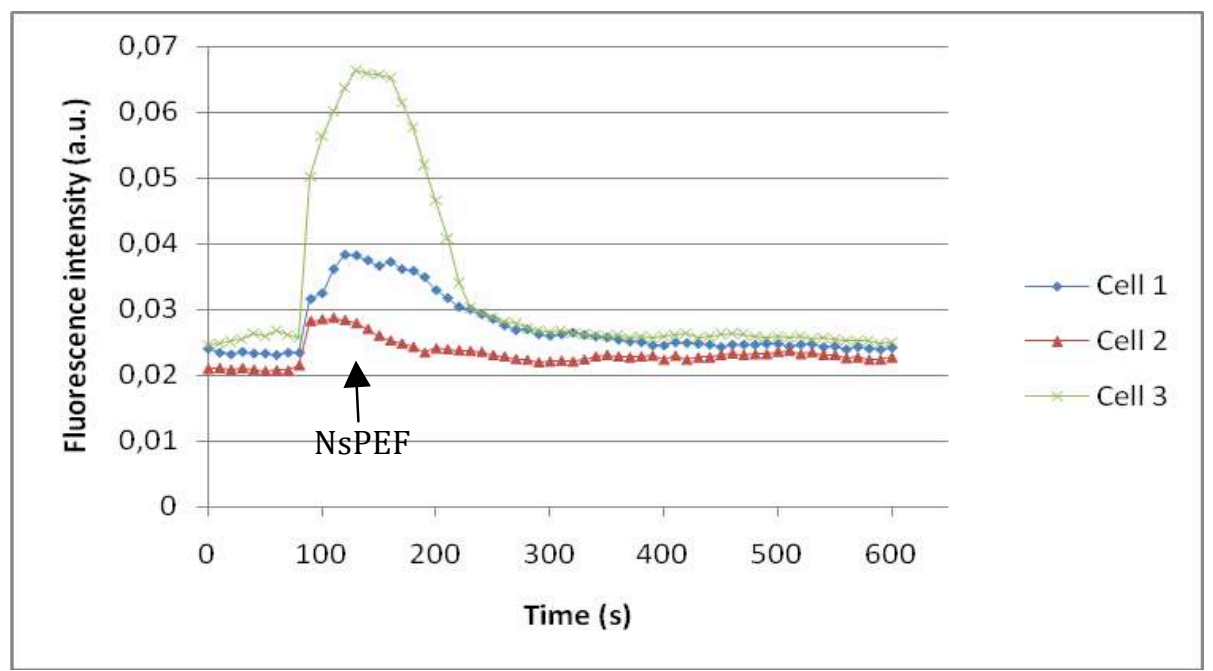

(b)

Figure 5: (a) Real time imaging of a calcium peak from cells imaged every $10 \mathrm{~s}$ with a $500 \mathrm{~ms}$ exposure. Attached DC-3F cells were loaded with the calcium marker Fluo-4 $(5 \mu \mathrm{M})$. A single $10 \mathrm{~ns}$ pulse of $280 \mathrm{kV} / \mathrm{cm}$ was delivered. A: $8 \mathrm{~s}$ before the nanopulse. B: $2 \mathrm{~s}$ after the nanopulse. C: $40 \mathrm{~s}$ after the nanopulse. D: $600 \mathrm{~s}$ after the nanopulse and (b) kinetics of the calcium response of the three cells observed in the previous figure

The kinetics of calcium response is reported on figure 5.(b) showing the immediate increase in fluorescence following the nanopulse delivery to the cells with a maximum value reached about $40 \mathrm{~s}$ after the nsPEF application. All the cells responded at the same time but the response amplitude was different from cell to cell (from a 0.5 fold increase to a 4 fold increase). Thus the nsPEFs applied to the DC-3F under the microdeviceassociated experimental conditions actually generate a cytoplasmic calcium concentration transient increase. 


\section{Conclusion}

An original microfluidic device dedicated to the application of nsPEFs to adherent cells and their real time monitoring has been developed and characterized in this work. The proposed device involves a removable packaging. Indeed, with such a packaging, the preparation of cell cultures on standard commercial slides remains possible, these slides being afterwards reported on the device for the nanopulses exposition and cell monitoring experiments. Two approaches have been compared in terms of microfabrication process and electric field homogeneity achieved in the microfluidic chamber. The efficiency of our device has been demonstrated with a successful study of the dynamics of the $\left[\mathrm{Ca}^{2+}{ }_{i}\right.$ in response to the application of nsPEF. The effect of extremely high amplitude and short duration electric pulses $(280 \mathrm{kV} / \mathrm{cm}, 10 \mathrm{nS})$ that could be applied for the first time to adherent cells, were recorded in real time in our microdevice. Kinetics of calcium responses show an increase in fluorescence due to the nanopulse application.

These promising results pave the way for the development of micro and nano systems well adapted to a better understanding of nanoporation effects on living cells.

\section{Acknowledgments}

This work was supported by the French National Agency through Nanoscience and Nanotechnology Program (Nanopulse-biochip n॰ ANR-08-NANO-024), CNRS, ENS de Cachan, Institut Gustave Roussy, University Paris-Sud, PRES Universud and CNANO'Ile de France.

\section{References}

[1] Domenge, C., Orlowski, S., Luboinski, B., De Baere, T., Schwaab, G., Belehradek Jr., J., Mir, L.M. (1996). Antitumor electrochemotherapy: New advances in the clinical protocol. Cancer, 77(5), 956-963.

[2] Marty, M., Sersa, G., Garbay, J.R., Gehl, J., Collins, C.G., Snoj, M., et al. (2006). Electrochemotherapy - An easy, highly effective and safe treatment of cutaneous and subcutaneous metastases: Results of ESOPE (European Standard Operating Procedures of Electrochemotherapy) study. Eur. J. Cancer Suppl. 4, 3-13.

[3] Mir, L.M., Bureau, M.F., Gehl, J., Rangara, R., Rouy, D., Caillaud, J.M., et al. (1999). High efficiency gene transfer into skeletal muscle mediated by electric pulses. Proceedings of the National Academy of Sciences of the United States of America, 96, 4262-4267. doi:10.1073/pnas.96.8.4262.

[4] Schwan, H.P. (1957). Electrical properties of tissue and cell suspensions. Advances in Biological and Medical Physics, 5, 147-209.

[5] Kotnik, T., Miklavcic ,D. (2000). Analytical description of transmembrane voltage induced by electric fields on spheroidal cells. Biophys. J. ,79, 670-679. 
[6] Miklavcic, D., Beravs, K., Semrov, D., Cemazar, M., Demsar, F., Sersa, G. (1998). The importance of electric field distribution for effective in vivo electroporation of tissues. Biophys. J., 74, 2152-2158.

[7] Kotnik, T., Miklavcic, D. (2006). Theoretical Evaluation of Voltage Inducement on Internal Membranes of Biological Cells Exposed to Electric Fields. Biophys. J., 90, 480491.

[8] Gowrishankar, T.R., Esser, A.T., Smith, K.C., Son, R.S., Weaver, J.C. (2011). Intracellular electroporation site distributions: Modeling examples for nsPEF and IRE pulse waveforms. Engineering in Medicine and Biology Society, EMBC, 2011 Annual International Conference of the IEEE, $732-735$.

[9]. Napotnik, T.B., Wu, Y.H., Gundersen, M.A., Miklavčič, D., Vernier, P.T. (2012). Nanosecond electric pulses cause mitochondrial membrane permeabilization in Jurkat cells. Bioelectromagnetics, 33(3), 257-264.

[10]. Vernier, P.T., Sun, Y., Marcu, L., Salemi, S., Craft, C.M., Gundersena, M.A. (2003). Calcium bursts induced by nanosecond electric pulses. Biochem. Biophys. Res. Commun., 310(2), 286-295.

[11] Craviso, G.L., Choe, S., Chatterjee, P., Chatterjee, I., Vernier, P.T. (2010). Nanosecond electric pulses: a novel stimulus for triggering Ca2+ influx into chromaffin cells via voltage- gated Ca2+ channels. Cellular \& Molecular Neurobiology, 30(8), 1259-1265.

[12] Huang, Y., Rubinsky, B. (2001). Microfabricated electroporation chip for single cell membrane permeabilization. Sens. Actuat. A: Phys. , 89(3), 242-249.

[13] Lin, Y.C., Jen, C.M., Huang, M.Y., Wii, C.Y., Lin, X.Z. (2001). Electroporation microchips for continuous gene transfection. Sens.Act.B.: Chem., 79, 137-143.

[14] Le Pioufle, B., Surbled, P., Nagai, H., Murakami, Y., Chun, K.S., Tamiya, E., Fujita, H. (2000). Living cells captured on a bio-microsystem devoted to DNA injection. Mater. Sci. Eng. C: Biomim. Supramol. Syst., 12(1-2), 77-81.

[15] Lee, W.G., Demirci, U., Khademhosseini, A. (2009). Microscale electroporation: challenges and perspectives for clinical applications. Integr. Biol., 1(3), 242-251.

[16] Wang, S.F., Chen, J.X., Chen, M.T., Vernier, P.T., Gundersen, M.A., Valderrabano, M. (2009). Cardiac Myocyte Excitation by Ultrashort High-Field Pulses. Biophys. J. , 96(4), 1640-1648.

[17] Dalmay, C, Villemejane, J., Joubert, V., Silve, A., Arnaud-Cormos, D., Français, O., Mir, L.M., Leveque, P., Le Pioufle, B., (2011). A microfluidic biochip for the nanoporation of living cells. Biosens. Bioelectron. , 26(12), 4649-4655.

[18] Dalmay, C., Villemejane, J., Joubert, V., Français, O., Mir, L.M., Le Pioufle, B., (2011). Design and realization of a microfluidic device devoted to the application of ultra-short pulses of electrical field to living cells. Sens. Act. B, 160(1), 1573-1580. 
[19] Silve, A., Vezinet, R., Mir, L.M. (2012). Nanosecond-duration electric pulse delivery in vitro and in vivo: experimental considerations. IEEE Trans. Instrum. Meas., 61(7), 1945-1954.

[20] Silve, A., Villemejane, J., Joubert, V., Ivorra, A., Mir, L.M. (2010). Nanosecond pulsed electric field delivery to biological samples: difficulties and potential solutions. In "Advanced Electroporation Techniques in Biology and Medicine", M. Markov, D. Miklavcic and A. Pakhomov Eds, CRC Press, Taylor \& Francis Group, pp. 353-368.

[21] Silve, A., Leray, I., Mir, L.M. (2011). Demonstration of cell permeabilization to medium-sized molecules caused by a single 10ns electric pulse. Bioelectrochemistry. In press.

[22] Kenaan, M., El Amari, S., Silve, A., Merla, C., Mir, L.M., Couderc, V., Arnaud-Cormos, D., Leveque, P. (2011). Characterization of a 50 Ohms Exposure Set-up for High Voltage Nanosecond Pulsed Electric Field Bioexperiments. Biomed. Eng. IEEE Trans. ,58(1), 207214. 